\section{Tokyo officials are told to agree on carbon strategy}

[токуо] Japan's Prime Minister, Ryutato Hashimoto, has called on senior ministers to sort out the country's policy on greenhouse gas emissions within two weeks, after growing international criticism of Japan's failure to make its position clear.

The vagueness of Japanese policy on reducing carbon dioxide emissions was criticized by Helmut Kohl, the German chancellor, at the recent meeting of the Group of Eight (G8) industrialized nations in Denver, Colorado. And there is increasing domestic con-

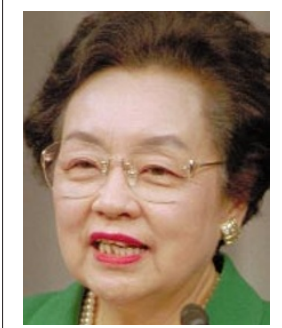
cern about prospects for the United Nations climate change conference, to be held in Kyoto in December.

Last week, Hashimoto called on Michiko Ishii, head of the Environment Agency, Yukihiko Ikeda, the foreign $\begin{array}{ll}\text { Ishii: needs a strategy } & \text { minister, and Shizuka } \\ \text { on } \mathrm{O}_{2} \text { emissions. }\end{array}$ Kamei, acting minister of trade and industry, to come up with a strategy that will lead to agreement at the conference, at which more than 150 countries have already agreed to set legally binding emission reduction targets.

Ministers are expected to announce Japan's plans to deal with global warming at a cabinet meeting within the next few days. There have been widespread reports of disagreement between the pro-business Ministry of Trade and Industry and the Environment Agency about reductions of greenhouse gas emissions (Nature 387, 641;1997).

Hironori Hamanaka, director general of the global environment department at the Environment Agency, denies there is a significant difference of opinion in the government. But he does not think Japan will have agreed reduction targets in time for an international preparatory meeting in Berlin next week.

Environment Agency officials also deny reports that Japan, together with Australia and the United States, is trying to persuade the European Union to withdraw its proposal for a reduction of 15 per cent in carbon dioxide emissions. Hamanaka says it is important for Japan to propose its own targets, but that a 15 per cent reduction is unrealistic.

Analysts in Tokyo think that without a revision to Japan's energy policy, it will be very difficult for the country to reduce carbon dioxide emissions at all. But international pressure on Japan is expected to mount in August when Germany's minister for the environment, Angela Merkel, visits Japan, and to intensify as the conference approaches.

RichardNathan

\title{
Australia to rejoin space race with satellite project
}

[SYDNEY] Australia is making a belated attempt to join the competition for a new generation of microsatellites with the approval of government support for the creation of a cooperative research centre (CRC) for satellite systems.

The centre plans to build a $50-\mathrm{kg}$ satellite for low-orbit experiments in communications, space physics, remote sensing and engineering. It will be launched in 2001 as an official part of the centenary celebrations of the federation of Australia's six states as an independent country, hence the project's name, FedSat-1.

With its base for military and civil tests at Woomera in the sparsely populated centre of the continent, Australia was in the forefront of space developments in the 1960s, a position enhanced by delays to the US manned flight programme after the fatal ground fire on Apollo 1.

In 1967, Australia became only the third country to launch a satellite from its own soil, placing one of the first X-ray telescopes in orbit. Built by the Weapons Research Establishment and the University of Adelaide, this was carried on an American military Redstone rocket.

But the rocket range fell into disuse after the cancellation of the British government's Blue Streak missile programme, which had been under test at Woomera, and the collapse of subsequent efforts to develop a civilian launcher through the European Launcher Development Organisation.

From the late 1980 s to early 1996 , the then
Labor government promoted Australia's potential as a launch site, whether for polar orbiting satellites from Woomera or nearequatorial launches from Cape York in the northeast. The bodies responsible for these efforts were disbanded to save money in the budget of August 1996.

But the science minister, Peter McGauran, retained A $\$ 2$ million (US $\$ 1.5$ million) a year and decided that a new CRC would specialize in space-related research. It was to be based on a group in the Commonwealth Scientific and Industrial Organization, the government's largest research agency, which is already carrying out remote sensing of Australia's vast land and ocean territory.

After delays in obtaining promises of collaboration from universities and small companies that produce components for satellites launched by other countries, the centre has now been approved, and its public funding increased to $\mathrm{A} \$ 20$ million over seven years, which is more than matched by contributions of A $\$ 36$ million from the partners.

Design and construction of the microsatellite will take place mainly in Adelaide, Canberra and Brisbane. Although the launch site and vehicle have yet to be decided, the centre's director, Brian Embleton, says a firm offer of a rocket has been received from the Japanese Space Agency, with expressions of interest from Russia and the United States. Embleton says Asian countries are keen to share payloads with the Australian project as an affordable means of obtaining information from space.

PeterPockley

\section{NIH and genome project set for more funds}

[WASHINGTON] The US National Institutes of Health (NIH) are on course for another substantial funding increase next year. Appropriators in the House of Representatives last week agreed a bill that will increase its budget by 6 per cent to $\$ 13.5$ billion, $\$ 400$ million more than requested by President Bill Clinton.

The increase, identified as a priority by both the chairman and the senior minority member of the Labor, Health and Human Services appropriations subcommittee, pleased lobbyists for biomedical research, who noted that the bill was passed without any unwanted earmarks or restrictive legislative riders.

The lobbyists are confident that the Senate appropriations subcommittee will approve an even larger increase for NIH when it addresses its own bill this week.
Senator Arlen Specter (Republican, Pennsylvania), who chairs the subcommittee, has said that he would try to secure a 7.5 per cent increase for the NIH.

The House bill proposes especially large increases for the National Institute of Human Genome Research - up by 12 per cent to \$211 million - and for the National Institute of Diabetes and Digestive and Kidney Diseases, up 7.5 per cent to $\$ 874$ million. These increases reflect Congress's enthusiasm for the Human Genome Project and its recent interest in diabetes research.

The bill passed by the House subcommittee also has modest increases for the Agency for Health Care Policy and Research, an agency targeted for deep cuts by conservatives in the previous Congress, and for the Centers for Disease Control and Prevention.

Colin Macilwain 